\title{
Author Correction: Pogz deficiency leads to transcription dysregulation and impaired cerebellar activity underlying autism-like behavior in mice
}

Reut Suliman-Lavie, Ben Title, Yahel Cohen, Nanako Hamada, Maayan Tal, Nitzan Tal, Galya Monderer-Rothkoff, Bjorg Gudmundsdottir, Kristbjorn O. Gudmundsson (1), Jonathan R. Keller, Guo-Jen Huang (D), Koh-ichi Nagata, Yosef Yarom \& Sagiv Shifman (iD

Correction to: Nature Communications https://doi.org/10.1038/s41467-020-19577-0, published online 17 November 2020.

The original version of the Supplementary Information associated with this Article omitted Table S3 and Table S4 due to a technical error. The HTML has been updated to include Table S3 and Table S4 as Supplementary Data associated with this Correction.

Published online: 17 June 2021

\section{Additional information}

Supplementary information The online version contains supplementary material available at https://doi.org/10.1038/s41467-021-24166-w.

\footnotetext{
(c) (i) Open Access This article is licensed under a Creative Commons Attribution 4.0 International License, which permits use, sharing, adaptation, distribution and reproduction in any medium or format, as long as you give appropriate credit to the original author(s) and the source, provide a link to the Creative Commons license, and indicate if changes were made. The images or other third party material in this article are included in the article's Creative Commons license, unless indicated otherwise in a credit line to the material. If material is not included in the article's Creative Commons license and your intended use is not permitted by statutory regulation or exceeds the permitted use, you will need to obtain permission directly from the copyright holder. To view a copy of this license, visit http://creativecommons.org/licenses/by/4.0/.
}

(C) The Author(s) 2021 